\title{
Review \\ How Cross-Discipline Understanding and Communication Can Improve Research on Multiracial Populations
}

\author{
Sarah E. Gaither ${ }^{1, *(1)}$ and Jennifer Patrice Sims ${ }^{2}$ (I) \\ 1 Department of Psychology and Neuroscience, Samuel DuBois Cook Center on Social Equity, Duke University, \\ Durham, NC 27701, USA \\ 2 Sociology Department, University of Alabama in Huntsville, Huntsville, AL 35899, USA; \\ jennifer.sims@uah.edu \\ * Correspondence: sarah.gaither@duke.edu
}

check for updates

Citation: Gaither, Sarah E., and Jennifer Patrice Sims. 2022. How Cross-Discipline Understanding and Communication Can Improve Research on Multiracial Populations. Social Sciences 11: 90. https:// doi.org/10.3390/socsci11030090

Academic Editors: David L. Brunsma Jennifer Sims and Nigel Parton

Received: 12 October 2021

Accepted: 17 February 2022

Published: 22 February 2022

Publisher's Note: MDPI stays neutral with regard to jurisdictional claims in published maps and institutional affiliations.

Copyright: (C) 2022 by the authors. Licensee MDPI, Basel, Switzerland. This article is an open access article distributed under the terms and conditions of the Creative Commons Attribution (CC BY) license (https:// creativecommons.org/licenses/by/ $4.0 /$ )
Abstract: One of the strengths of Critical Mixed Race Studies is that it represents research methodologies and frameworks from multiple disciplines across the social sciences and humanities. However, if these disciplines are not in dialogue with each other, that benefit may be lost. Here, we use psychological and sociological research on Multiracial populations as examples to argue how strict disciplinarity and methodological trends may limit scientific production. We propose that reading and citing work across disciplines, expanding methodological training, and rejecting hegemonic "white logic" assumptions about what is "publishable" can enhance Multiracial research. First, the ability to cite effectively across disciplines will shorten the time it takes for new theories to be developed that focus on empirically underrepresented populations. Secondly, increasing understanding of both quantitative and qualitative methods will allow more effective reading between disciplines while also creating opportunities to engage with both causality and the richness of experiences that comprise being Multiracial. Finally, these changes would then situate scholars to be more effective reviewers, thereby enhancing the peer-reviewed publication process to one that routinely rejects color evasive racist practices that privilege work on majority populations.

Keywords: multiracial; mixed race; critical mixed race studies; psychology; sociology

\section{Introduction}

"A diversity science will consider how people create, interpret, and maintain group differences among individuals, as well as the psychological and societal consequences of these distinctions."-Victoria Plaut (2010)

The academic field of Critical Mixed Race Studies (CMRS) stands as an explicit example of the exact type of diversity science that Plaut (2010) described above. As explained by Sims and Joseph-Salisbury (2019), CMRS has emerged over the last few decades and has "established itself as a distinct academic field" as "evidenced by the rise in academic publications that focus on mixedness, a rise in the number of academics who identify as CMRS scholars, the hosting of a regular international CMRS conference, and the establishment of a CMRS journal" (p. 51; see also Daniel et al. 2014).

The Multiracial population (those who identify with more than one racial/ethnic group; see Sanchez et al. 2020 for capitalization support) has long been studied in the U.S. across various fields and disciplines with the notion of trying to document what experiences are unique to this growing demographic who challenge U.S. conceptions of race (for reviews, see Daniel et al. 2014; Pauker et al. 2018; Shih and Sanchez 2009). CMRS, as an academic field, spans across research disciplines that examine race, ethnicity, and culture. Specifically, CMRS largely argues for a commitment to highlighting both the historical and modern-day significance of being Multiracial. However, we argue that disciplinespecific practices over time have harmed the field's ability for further theory development 
in addition to creating publication biases on the type of empirical findings that are valued. Importantly, we are not calling for an increased use of mixed-methods approaches. Rather, we believe to advance the CMRS field, we need increased cross-discipline understanding and communication. Specifically, simply citing outside of one's discipline will not aid in expanding multidisciplinary understandings.

As example case studies, we will use psychology and sociology (the areas of focus of the authors of this paper) - two disciplines that have been at the forefront of studying Multiracial experiences in line with CMRS approaches-to demonstrate key disciplinespecific differences that, when underacknowledged, have led to duplicate work and limited abilities to truly understand the Multiracial experience. Moreover, these two fields have also largely function distinctly from each other due to methodological and training differences. Thirty years ago, psychologist Maria P. P. Root opened her seminal edited volume Racially Mixed People in America with the following quote: "The topic of racially mixed persons provides us with a vehicle for examining ideologies surrounding race, race relations, and the role of the social sciences in the deconstruction of race" (Root 1998, p. 10). Similarly, sociologist Kerry Ann Rockquemore (1998, p. 198) explained that, due to racial stratification, "society has continually had to develop norms to classify individuals who straddle the socially constructed boundaries;" and for this reason, research on mixed-race populations can reveal the social factors that influence phenomena such as "identity construction and maintenance".

It is important to note that psychology as a field uses the terms Multiracial and Biracial most often, while sociology uses those terms in addition to the term mixed-race. Notably, members of the mixed-race community racially identify in very different ways, with some even choosing to identify as "human" in an attempt to avoid racial essentialized categorization (Rockquemore and Brunsma 2002; although racialization norms can still be used by perceivers regardless of one's label choice, for example, see Hernández 2018). Since this paper reflects on psychology and sociology while also considering a CMRS framework, we are using these terms interchangeably since Multiracial labels have also shifted and changed over time.

Building upon the foundational work in their respective fields and following a CMRS approach, psychologists and sociologists have continued to research and theorize about Multiraciality. Nonetheless, this research has been mostly completed separately by each field, respectively, with only a few exceptions (e.g., Root, Rockquemore, and Brunsma). However, we agree with Rockquemore et al. (2009, p. 24) that CMRS will become repetitive, lackluster, and theoretically ineffective if scholars "are not engaged in conversation with each other, do not actively cite studies outside their disciplinary and methodological approach, and are seemingly unaware of their disciplinary limitations." While it is true that this critique could apply to any area of research, we feel that the need for cross-discipline understanding and communication is particularly strong for Multiracial research as a young field that continues to grow.

In response to Rockquemore et al.'s (2009) call for improved cross-disciplinary communication, in the present paper, we draw on examples from our own and other psychological and sociological work on mixed-race people to demonstrate the importance for CMRS specifically and all sciences more broadly. First, we explain the downsides of the insular citation practices Rockquemore and others have critiqued, and we show the benefits to each discipline of expanding the conversation. Secondly, we argue that to facilitate cross-discipline connection, both individuals and institutions need to prioritize increasing understanding of different methodologies. Finally, we conclude by encouraging scholars to use their cross-disciplinary knowledge and methodological breadth to critically assess emerging publishing conventions with respect to the potential disparate negative impact on work with small populations such as mixed-race people. 


\section{2. "Research Has Largely Ignored ... ": The Downsides of Insular Citation Practices}

The common phrase "research has largely ignored" implies that no research in any field or discipline has explored that particular question. However, because so many social science disciplines live in relative isolation from each other (Fourcade et al. 2015; Jacobs 2013), when phrases such as this are written in academic papers, it is likely that a particular author has not thoroughly checked other disciplines. In this way, the typical insularity that is academic research contributes to and exacerbates false claims that "this paper is the first" to study a given question.

It is a disservice to knowledge production on a given topic if researchers only consider work on that topic produced by others in their same discipline. One example of this that we see in psychological and sociological work on Multiraciality is missing opportunities to use the published work from other disciplines to enhance existing theories. Since effective and valuable theories cannot be developed until there is enough converging evidence on a given question, missing opportunities to build on existing literature by reading outside of one's discipline stalls the knowledge production process.

For example, in a recent psychological paper, the first author of the present paper, wrote that "biracial research has largely ignored the intersections between being biracial and other social identities such as gender" (Gaither 2018, p. 449). That same year, the second author of the present paper presented a paper at a sociology conference that argued that too little research on mixed-race identity paid attention to the life course, in particular to adult identity changes (Sims 2018). Neither of those assertions of understudied topics within CMRS are tenable, however, because there is work in sociology that has focused on the intersections of mixed-race and gender identities, and there is work in psychology that measures variable lifespan identity outcomes for the Biracial population.

To elaborate, sociological research on mixed-race people has always been attentive to the ways in which gender intersects with race to influence identity and experiences. For example, it is a robust empirical finding that more women than men identify as mixed-race than with a singular race (e.g., Davenport 2016; Lopez 2003; Song and Aspinall 2012). The sociological literature offers several theories as to why. One is that there are gender differences regarding identity-salient interpersonal interactions with peers and strangers (Khanna 2011; Rockquemore and Laszloffy 2005; Sims 2016; Sims and Joseph-Salisbury 2019). Men being perceived as "more rigorously racialized than women" has also been theorized (Davenport 2016; Vasquez 2010, p. 45). In addition, sociological work has examined the intersection of being mixed-race and one's gender identity via conducting focused studies of cis women (e.g., Ifekwunigwe 1999; Joseph 2013; Rockquemore 2002; Rockquemore and Brunsma 2004; Tate 2007; Thompson 2000), trans women (Buggs 2020), and cis men (Joseph-Salisbury 2018; Long and Joseph-Salisbury 2019; Newman 2019; Sims and Joseph-Salisbury 2019).

Within the last decade, psychology has begun to highlight how both race and gender directly influence social interactions, perceptions, and ultimately identity for racial minority populations (e.g., Galinsky et al. 2013; Ghavami and Peplau 2013; Johnson et al. 2012). However, this work examining some of the interactions between race and gender could be strengthened if psychologists were in dialogue with sociologists, since so much of sociology has focused on the within-group differences that psychology at times overlooks. For instance, in the first author's 2018 paper, she observes that psychological research has traditionally used a singular identity framework when theorizing about the role of identity for shaping behaviors. Assuming identity follows a simple ingroup/outgroup framework ignores the intersections with other important identities. Focusing on Biracial individuals as an exemplar case, she advocates for moving beyond an either/or binary construct of identity by demonstrating the potential impact of multifaceted self-views on behaviors. However, her call for new models and mechanisms for understanding the multiplicity of belonging could have been even more robust had it incorporated existing sociological work. For example, by drawing on sociological theories regarding how race is always gendered 
(e.g., Ali 2003; Tate 2005), she could have further strengthened the point that individuals do not experience a given identity in a singular, isolated fashion.

On the other hand, sociological studies of mixed-race people typically use samples composed mainly of young adults from whom data are collected at one-time point. Accordingly, little of the early mixed-race work within sociology addressed how lifespan experiences influence mixed-race identity development (but see Campbell and EggerlingBoeck 2006; Harris and Sim 2002; Hitlin et al. 2006 as exceptions). Psychology, by contrast, has decades of published work focusing on the lifespan development of Multiracial identity (e.g., Nishina and Witkow 2020; Poston 1990; Shih and Sanchez 2009). First, across early childhood, some work has documented distinct identity and ingroup preference development for Biracial versus monoracial children (e.g., Echols and Graham 2018; Gaither et al. 2014; Roberts and Gelman 2017). Moreover, other research with adolescents and young adults highlights that variations in Multiracial identification over time are associated with both the racial and ethnic socialization they receive from families and peers in addition to experiences of identity denial and questioning being identified as key psychological experiences that impact one's Multiracial identity (e.g., Albuja et al. 2019a, 2019b; Brittian et al. 2013; Franco and Franco 2015; Herman 2004; Mihoko Doyle and Kao 2007; Rivas-Drake et al. 2014; Root 1998).

Within the last decade, sociologists have begun to examine the impact of later lifespan events on the identity development of mixed-race populations (e.g., Clayton 2019; Roth and Ivemark 2018; Saperstein and Penner 2010; Sims 2018). However, as was the case for psychology, these sociological theories could be improved if sociologists were in better dialogue with psychologists. For example, in one section of the second author's 2018 conference paper she discussed the impact of graying and hair loss on others' racial perception of mixed-race people and thus their identity development via reflected appraisals (see Khanna 2004, 2010; Sims 2016). To illustrate, one of her 30-year-old interviewees reported that he purposefully wears his hair in a large afro so that others can identify him as a Black man, and he worried that as he ages and loses his hair that he will increasingly be perceived by others as non-Black (see Feliciano 2016; MacLin and Malpass 2001; Sims et al. 2020 on the impact of hairstyle changes on how people are viewed racially). The second author concluded that physical changes may influence racial identity changes via this pathway, but she could have strengthened this point via engagement with psychological research on self-perceptions and self-esteem in late adulthood (e.g., Menkin et al. 2017; Westerhof et al. 2012).

Thus, the limited awareness of the work in relevant related disciplines puts CMRS scholars at risk of developing partial and incomplete theories. We propose that normalizing and prioritizing the reading, understanding, and citing of related research in other disciplines will be the most efficient way to create efficacious theories, especially within fields such as CMRS, which studies underrepresented and historically ignored populations. In fact, as it relates to Multiracial research, two recent reviews in psychology highlighted how race-related research has been rare across the past 50 years in psychological science (Roberts et al. 2020) and Multiracial research specifically has been "white-centered", which limits our understanding of all Multiracial experiences (Garay and Remedios 2021). These reviews therefore provide even more support for increasing an understanding of other disciplines such as sociology that have researched race-related experiences more extensively to effectively advance Multiracial identity theories.

In sum, as two related but clearly distinct disciplines that both examine aspects of Multiracial identity and experiences, psychology and sociology demonstrate the pitfalls of narrow, insular reading as well as the latent value to each discipline's knowledge production process of reading more broadly. As Fourcade et al. (2015) said in their paper about academic insularity, "human life is messy, never to be grasped in its full complexity or shaped according to plan: people act in unanticipated ways; politics makes its own demands; cultures resist" (p. 111). This quote dovetails nicely with Plaut's (2010) definition of diversity science noted at the beginning of this paper. In other words, we must consider 
group differences and the consequences of those differences so that we are honest and accurate about the lived experiences of all groups. Thus, without acknowledging research outside of one's specific discipline, we will likely miss critical findings that can shape how we think about our research topics within our own discipline while also expanding the knowledge about historically underrepresented groups in our science.

\section{Expanding Methodologies: The Case for Quantitative and Qualitative Training for Psychologists and Sociologists}

Relatedly, in order to properly read and understand findings from outside of one's primary discipline, CMRS scholars need to have the academic tools to assess both quantitative and qualitative research. As an example, one specific barrier to psychological and sociological CMRS scholars engaging with each other lies in disciplinary-specific methods training. Methodologically, psychology and sociology differ, and their respective work on race demonstrates this. Psychological work on the Multiracial population has emphasized experimental findings as they relate to testing for causality (but see Brittian et al. 2013; Herman 2004; and Straka et al. 2020 as examples of secondary data analyses and descriptive surveys) and has focused heavily on perceptions and/or social categorizations of mixed-race faces (e.g., Chen 2019; Pauker et al. 2018; Young et al. 2021). Sociological work on the mixed-race population rarely uses experiments (for exceptions see Feliciano 2016; Sims et al. 2020; Stockstill 2018). Instead, sociologists employ a variety of quantitative and qualitative methods. Sociology often uses surveys (e.g., Rockquemore and Brunsma 2002; Brunsma 2006; Bratter and Damaske 2013; Davenport 2016), interviews (e.g., Rockquemore 1998; Khanna 2004, 2010; Pilgrim 2021; Sims 2016), autoethnography (e.g., Buggs 2017), and comparative-historical analyses (e.g., Morning 2012; Sims and Njaka 2020; Pirtle 2021). Moreover, sociology explicates mixed-race group-level social trends and theorizes the role of history, context, and intersectional identities on group-level and social psychological experiences. While these discipline-based approaches are different, we argue that they are also complimentary. Thus, it would enhance future CMRS research if more scholars could understand and incorporate insights from both methodological approaches into their work. Importantly, we are not asking for all CMRS scholars to use a mixed-methods approach in their work, nor are we asking for CMRS scholars to increase their collaborations across disciplines. However, we do believe that if the training changed across disciplines to allow CMRS scholars to at least have access to knowledge relating to these different methodological tools, it would strengthen Multiracial research significantly.

To expand, one vibrant area of CMRS work (and, as mentioned, psychology specifically as a discipline) examines how mixed-race people are perceived by others and how that categorization process may shift various types of attitudes such as essentialism (i.e., the belief that race is a fixed or stable category). Hypodescent is one popularly used term to describe how some Multiracial people are perceived-more often as their minority group membership (i.e., a Biracial Black/White person would be categorized more often as Black). Also known as the "one drop rule" (Banks and Eberhardt 1998; Davis 1991), hypodescent is historically rooted as an anti-miscegenation law to limit rights for anyone known to have Black ancestry. Experimental work has directly tested this definition and shown that both Biracial Asian/White and Biracial Black/white individuals are more often categorized as Asian and Black, respectively (Ho et al. 2011). It is the racial ambiguity that experimental research has operationalized as being equated (perhaps incorrectly at times) with being Multiracial that causes perceivers to take longer to cognitively process the targets, which leads to hypodescent or a minority bias being a dominant shortcut in visual processing (e.g., Chen and Hamilton 2012; Chen et al. 2014; Freeman et al. 2016). Moreover, other recent work has also shown that exposure to Multiracial people can reduce essentialist beliefs since the Multiracial population directly contradicts more fixed ways of considering race (e.g., Gaither et al. 2018; Sanchez et al. 2015). Thus, one result of psychology's dominant use of experimental and quantitative methods is that this approach allows them to pinpoint causality, which has added empirical support to identity flexibility theories. 
Nevertheless, these methodologies do not always highlight the individual differences within or the impact of the regional or national contexts on how Multiracial individuals are perceived by others (but see Chen et al. 2018; Pauker et al. 2018 for exceptions that consider context). In fact, a recent meta-analysis in psychology found that hypodescent outcomes are seen more reliably with white-only participant samples, forced-choice dichotomous categorization methods (e.g., is this face Black or white), and Biracial Black/white and male stimuli (Young et al. 2021), suggesting psychology as a field still does not fully understand which contexts and individual differences shift Multiracial perceptions.

However, one related psychology paper informed by sociological work was by Pauker et al. (2018), which showed longitudinally that the racial diversity of one's environment over time can also lead to a reduction in these same essentialist beliefs. Specifically, they show that white individuals who live in more diverse areas such as Hawaii, which has a large Multiracial population, demonstrate reductions in essentialism. However, without theoretical framing additions from sociologists and philosophers who focused on aspects of interracial friendships and social categorization processes (Hallinan and Williams 1987; Mallon 2007), this paper would not have been properly grounded in existing theory.

By contrast, qualitative sociological work on the identification of mixed-race people by hypodescent offers rich details about individual, sub-population, and contextual trends that influence how perceivers see mixed-race people (e.g., Bratter 2007; Brunsma and Rockquemore 2002; Khanna 2004, 2010; Pilgrim 2021; Waring and Purkayastha 2017). For example, in interview studies, mixed-race individuals describe actual experiences with hypodescent, such as when a mixed-race Black/white man's boss questioned the white racial identity he marked on his application, saying "shouldn't you just put Black?" (Sims and Njaka 2020, p. 34). How these experiences are felt, processed, and understood to influence one's identity, and the fact that they differ by race, appearance, gender, class, sexual orientation, nationality, and more are insights from in-depth interviews that one cannot obtain using standard experimental methods. Thus, qualitative sociological CMRS has been able to reveal the rich details of Multiracial experiences with hypodescent, which are often overlooked within larger quantitative samples. Since qualitative work focuses on meaning making not on quantifying relationships between variables, the robustness of a qualitative study is not inherently enhanced simply by increasing one's sample size. In general, quantitative methods tend to be prioritized across disciplines, but we argue that, without truly understanding both quantitative and qualitative methods, only portions of CMRS findings can be properly understood.

Nonetheless, qualitative results cannot reveal causality nor typically can they be generalized beyond the published research sample. Thus, qualitative sociological work within CMRS is enhanced when it explicitly engages with the group-level processes and patterns discovered by experimental psychologists. For example, in her work on mixed-race women's conceptualization of interracial relationships, Buggs (2019) explains how one view that her interviewees expressed was that racial minority familial resemblance was undesirable in a future partner. One such undesirable resemblance for her mixed-race Asian interviewees was a man who spoke English with an "Asian" accent versus speaking "unaccented" English. Buggs' conclusion, after juxtaposing this with her finding that mixed-race women did not consider resemblance to their white family members undesirable, was that discounting a person as a potential partner due to their accent represents an "internalized anti-Asian dating schema that rendered Asian men less attractive partners" (p. 1232). Buggs briefly mentions an experimental psychology study (Dixon et al. 2002) that also found expressions of prejudice towards men perceived as having a non-dominant accent. In so doing, she was not implying that her interview-based findings were invalid but was complementing and strengthening her interview-based conclusion even more by demonstrating that multiple methodologies across two different disciplines have documented the same process. This type of converging evidence only strengthens a finding, which is why disciplines need to communicate with each other more often, especially when working with underrepresented samples. 
In sum, it is clear that experimental psychology significantly contributes to the causal and generalizable nature of what it is scholars understand about Multiracial experiences, but sociology, in particular qualitative sociology, adds just as much by ensuring that the rich details of mixed-race experiences and the impact on them of larger social forces are not overlooked. Therefore, we propose that researchers should prioritize not just respecting but actually understanding and citing work on their topic of focus from outside of their methodological niche.

To facilitate this, at the institutional level, requirements in both psychology and sociology graduate programs should be revised to provide all junior scholars with a more robust methodological background or at least exposure. A glance at the methods courses offered by the top ten programs in psychology and sociology (according to the U.S. News and World Reports) reveals that statistics courses are required at all the top ten programs in both disciplines. By contrast, none of the top ten programs in psychology offers a qualitative research methods course; and even though all the top ten sociology programs do offer qualitative methods courses, a course is only a requirement in two programs.

This imbalanced education negatively prepares psychology and sociology graduates to be holistic researchers. The ability to properly understand experimental, quantitative, and qualitative methods will enhance scholars' ability to read more outside of their disciplinethe first call to action in this paper. Moreover, this same expansion of methodological knowledge acquisition may also make the reviewing process more inclusive and comprehensive for scholars who study Multiracial topics in any field-the second call to action in this paper.

\section{4. "I Recommend That the Authors Replicate This with a Larger Sample:" Emerging Publishing Conventions and the Value of Highlighting the Scientific Contributions of Various Methodologies}

As argued in the preceding sections above, scholars being familiar with the existence of mixed-race research from other fields and being trained to understand experimental, quantitative, and qualitative methods, would enhance psychological and sociological scholarship by increasing the depth and breadth of theorizing from results. In addition, since scholars from both disciplines serve as peer reviewers for academic journals (journals in their home disciplines as well as more general social psychology and identity-focused journals), being unaware of Multiracial research from other fields and unfamiliar with various methodologies can negatively impact reviewing and editorial decisions, which ultimately can also lead to various publication biases in what is considered "science".

For example, as noted above, both disciplines' graduate training prioritizes quantitative methodologies over qualitative methodologies. This prioritization is at risk of being further institutionalized as both disciplines increasingly privilege publishing work based on research utilizing increasingly larger sample sizes (Anderson et al. 2019; Deterding and Waters 2018). In psychology, Anderson et al. (2019) reviewed 240 papers from the top three social psychology journals and found that multi-study packages and high-powered online samples were being prioritized in these journals. Moreover, they stressed that this push in the field for large online samples (see also Charmaraman et al. 2014 for a metaanalysis of Multiracial research highlighting the common use of large surveys) will end up overshadowing more difficult-to-conduct studies and hard-to-reach populations while psychology continues to value convenience samples. They wrote: "Brief, online studies may be able to answer a few relevant questions in these domains, but much more-in-depth, time-consuming, difficult-to-conduct studies are also necessary to develop useful theories and workable interventions" (Anderson et al. 2019, p. 848).

Since qualitative work does not focus on quantifying relationships between variables, the robustness of a qualitative study is not inherently enhanced simply by increasing the sample size. Nonetheless, Deterding and Waters (2018) content analysis of the 98 qualitative interview studies published in the top five sociology journals from 2010-2015 revealed the same trend towards increasingly larger sample sizes. They report that "the number of interviews ranged from 12 to 208 ", that "the median number for the whole set is 55", and 
that "one in four articles (24 total) reported on 100 or more interviews" (p. 11). Speculating as to what is driving this upward trend, they hypothesize that qualitative researchers' contemporary desire to "highlight contrasts between groups of respondents or research sites" (p. 12) necessitates having enough interviewees in each group or at each site to be able to identify patterns.

Although there is ample statistical evidence to support the need for high-powered studies, the trend towards privileging publication of only larger studies in top journals disadvantages research in fields like CMRS since small populations are much more costly to recruit compared to majority samples. Experimental psychologists who study the Multiracial population cannot quickly or easily obtain 500 participants from a General Psychology course (nor can other researchers focused on other historically underrepresented groups). Likewise, neither quantitative nor qualitative sociologists can quickly obtain hundreds of mixed-race people to fill out a survey or participate in an interview like sociologists who study more easily recruited populations.

In addition to recruiting study participants from a minority population being more time-consuming, it is also considerably more financially costly than recruiting majority samples (Gaither 2019). In a study, the first author recruited online during summer 2020; she was charged \$27 per Multiracial participant compared to $\$ 5.50$ per monoracial participant due to the fact that Multiracial individuals were so vastly underrepresented on the Qualtrics Panels Services compared to monoracial individuals. Similarly, in sociology, it is, of course, preferable to offer interviewees some compensation (USD 5-10 at the very least) for giving a researcher an hour or more of their time. As such, a publication threshold that requires 100-200 participants per study is disproportionately financially burdensome for qualitative CMRS researchers as well.

Left unchecked, new norms of requiring higher-powered studies (Lindsay 2015; Vazire 2015) will stifle research on certain topics or turn research and high-impact publishing on Multiracial populations into an activity that only those with advanced quantitative skills, access to costly technologies, and/or membership on well-funded research teams can do. As small studies were the foundational works on which others began to build (e.g., Rockquemore 1998), this trend would be a great loss for CMRS. The broader impact to science and society, as Anderson et al. (2019, p. 848) remind us, is that "if we disproportionately allocate resources (e.g., publications, tenure) to researchers and research domains that eschew difficult-to-conduct studies, then we impair the field's ability to contribute to human welfare".

Given the barriers to acquiring large Ns from small minority populations such as mixed-race people as well as the non-necessity of it for certain types of research, both disciplines' trends to prioritize increasingly larger sample sizes can be critiqued as "white logic and methods" (Zuberi and Bonilla-Silva 2008). In fact, Anderson et al. (2019) wrote in their suggestions for the psychology field: "Consider the trade-offs associated with emphasizing some scientific goals (e.g., replicability) over others (e.g., external validity) desirable characteristics for high-quality science are often at odds with one another and no single study can include all desirable characteristics". Although it is certainly true that replicability is higher with larger samples and increased power (e.g., Bertamini and Munafò 2012; Button et al. 2013; Vankov et al. 2014), focusing on certain goals to the exclusion of others as a field is likely to create new problems while solving others. Moreover, a recent review paper in psychology argues that the white-centering research practices in psychology, often due to sample size requirements, lead to misrepresentations of Multiracial outcomes while also focusing primarily on white-identified Multiracial individuals too often (Garay and Remedios 2021). However, recruiting a large enough sample of dual minority Multiracial individuals would take more than twice the amount of time and money. Acknowledging such trade-offs can help us maintain balance. In other words, it would be both elitist and racist to assume that studies with very large sample sizes are automatically more robust, scientific, and deserving of publication in top-tier journals than studies with smaller sample sizes. 
Psychology's and sociology's methodological trend toward bigger data, though, no doubt stems from quantitatively-biased yet hegemonic views of what methodologies are "objective" (Zuberi and Bonilla-Silva 2008). As many have written, "objectivity" has traditionally been synonymous with white male-centered ideas and methods while counterhegemonic thoughts and practices have been "othered" as lacking "scientific rigor" (Buggs et al. 2020; Collins [1990] 2000; Thomas 2017; Zuberi and Bonilla-Silva 2008). Journal and reviewer expectations for increasingly larger samples may thus become the newest color evasive mechanism to delegitimize research on minority groups.

However, if psychological and sociological scholars become better versed in different methodologies in graduate school, as we suggested above, they will be less likely to fall into this ideological trap. They will be able to be more effective peer reviewers, that is, reviewers who are open to the goals of that paper and whether a larger sample size is in fact feasible and/or helpful for the given research question. In short, to move forward, we need our reviewing and publishing systems to truly value the multiplicity of social science perspectives, methods, and approaches.

\section{Conclusions}

From reflection on psychological and sociological research on Multiracial populations, we have demonstrated how strict disciplinary citation practices, narrow methodological understanding, and recent publishing trends may limit the scientific production needed to create more Multiracial-specific theories. What is clear across both disciplines is that Multiracial experiences are often unique compared to their monoracial counterparts and so both disciplines must continue to develop robust empirically validated theories to explain Multiracial experiences. We propose that reading and citing work from other fields, facilitated by expanding methodological training, and rejecting hegemonic assumptions about what type of work is suitable for high impact generalist journals can enhance Multiracial research in particular and all research in general.

Multiracial individuals reflect one of the fastest growing demographics in the U.S. (e.g., Colby and Ortman 2015; Lee and Bean 2004; Livingston 2017; Pew Research Center 2015). Additionally, increases in immigration and the changing demographics of the mixed-race population (e.g., see Waring and Purkayastha 2017) further establishes why research on and by these populations cannot regress to the historic norm of exclusion and suppression (Collins [1990] 2000). The interdisciplinary field of CMRS continues to be an example of the type of rigorous diversity science that Plaut (2010) said is needed. However, because it is not the only one, we believe that all science, not just CMRS, would benefit from increasing cross-discipline understanding and communication.

Funding: This research received no external funding.

Institutional Review Board Statement: Not Applicable.

Informed Consent Statement: Not Applicable.

Data Availability Statement: Not Applicable.

Conflicts of Interest: The peer review process for this article was managed by the journal editors, not the special issue co-editors. Thus, the authors declare no conflict of interest.

\section{References}

Albuja, Analia F., Diana T. Sanchez, and Sarah E. Gaither. 2019a. Identity denied: Comparing American or white identity denial and psychological health outcomes among bicultural and biracial people. Personality and Social Psychology Bulletin 45: 416-30. [CrossRef] [PubMed]

Albuja, Analia F., Sarah E. Gaither, Diana T. Sanchez, Brenda Straka, and Rebecca Cipollina. 2019b. Psychophysiological stress responses to bicultural and biracial identity denial. Journal of Social Issues 75: 1165-91. [CrossRef]

Ali, Suki. 2003. Mixed-Race, Post-Race: Gender, New Ethnicities and Cultural Practices. Oxford: Berg Publishers.

Anderson, Craig A., Johnie J. Allen, Courtney Plante, Adele Quigley-McBride, Alison Lovett, and Jeffrey N. Rokkum. 2019. The MTurkification of social and personality psychology. Personality and Social Psychology Bulletin 45: 842-50. [CrossRef] [PubMed] 
Banks, R. Richard, and Jennifer L. Eberhardt. 1998. Social psychological processes and the legal bases of racial categorization. In Confronting Racism: The Problem and the Response. Edited by Jennifer L. Eberhardt and Susan T. Fiske. Thousand Oaks, CA: Sage Publications, Inc., pp. 54-75.

Bertamini, Marco, and Marcus R. Munafò. 2012. Bite-size science and its undesired side effects. Perspectives on Psychological Science 7: 67-71. [CrossRef] [PubMed]

Bratter, Jenifer. 2007. Will "multiracial" survive to the next generation?: The racial classification of children of multiracial parents. Social Forces 86: 821-49. [CrossRef]

Bratter, Jenifer L., and Sarah Damaske. 2013. Poverty at a Racial Crossroads: Poverty Among Multiracial Children of Single Mothers. Journal of Marriage and Family 75: 486-502. [CrossRef]

Brittian, Aerika S., Adriana J. Umaña-Taylor, and Chelsea L. Derlan. 2013. An examination of biracial college youths' family ethnic socialization, ethnic identity, and adjustment: Do self-identification labels and university context matter? Cultural Diversity and Ethnic Minority Psychology 19: 177-89. [CrossRef] [PubMed]

Brunsma, David L. 2006. Public categories, private identities: Exploring regional differences in the biracial experience. Social Science Research 35: 555-76. [CrossRef]

Brunsma, David L., and Kerry Ann Rockquemore. 2002. What does "Black" mean? Exploring the epistemological stranglehold of racial categorization. Critical Sociology 28: 101-21. [CrossRef]

Buggs, Shantel Gabrieal. 2017. 'Your momma is day-glow white': Questioning the politics of racial identity, loyalty and obligation. Identities 24: 379-97. [CrossRef]

Buggs, Shantel Gabrieal. 2019. Color, culture, or cousin?: Multiracial Americans and framing boundaries in interracial relationships. Journal of Marriage \& Family 81: 1221-36. [CrossRef]

Buggs, Shantel Gabrieal. 2020. (Dis)Owning Exotic: Navigating Race, Intimacy, and Trans Identity. Sociological Inquiry 90: 249-70. [CrossRef]

Buggs, Shantel Gabrieal, Jennifer Patrice Sims, and Rory Kramer. 2020. Rejecting white distraction: A critique of the white logic and white methods in academic publishing. Ethnic and Racial Studies 43: 1384-92. [CrossRef]

Button, Katherine S., John Ioannidis, Claire Mokrysz, Brian A. Nosek, Jonathan Flint, Emma S. J. Robinson, and Marcus R. Munafò. 2013. Power failure: Why small sample size undermines the reliability of neuroscience. Nature Reviews Neuroscience 14: 365-76. [CrossRef]

Campbell, Mary E., and Jennifer Eggerling-Boeck. 2006. "What about the children?" The psychological and social well-being of multiracial adolescents. The Sociological Quarterly 47: 147-73. [CrossRef]

Charmaraman, Linda, Meghan Woo, Ashley Quach, and Sumru Erkut. 2014. How have researchers studied multiracial populations? A content and methodological review of 20 years of research. Cultural Diversity and Ethnic Minority Psychology 20: 336-52. [CrossRef]

Chen, Jacqueline M. 2019. An integrative review of impression formation processes for multiracial individuals. Social and Personality Psychology Compass 13: e12430. [CrossRef]

Chen, Jacqueline M., and David L. Hamilton. 2012. Natural ambiguities: Racial categorization of multiracial individuals. Journal of Experimental Social Psychology 48: 152-64. [CrossRef]

Chen, Jacqueline M., Wesley G. Moons, Sarah E. Gaither, David L. Hamilton, and Jeffrey W. Sherman. 2014. Motivation to control prejudice predicts categorization of multiracials. Personality and Social Psychology Bulletin 40: 590-603. [CrossRef]

Chen, Jacqueline M., Maria Clara P. de Paula Couto, Airi M. Sacco, and Yarrow Dunham. 2018. To be or not to be (black or multiracial or white) cultural variation in racial boundaries. Social Psychological and Personality Science 9: 763-72. [CrossRef]

Clayton, Kristen. 2019. Black-white biracial students' evaluations of Blackness: The role of college in shaping racial regard. Sociology of Race and Ethnicity 5: 70-84. [CrossRef]

Colby, Sandra L., and Jennifer M. Ortman. 2015. Projections of the Size and Composition of the U.S. Population: 2014 to 2060 (Vol. P25-1143, Current Population Reports); Washington, DC: U.S. Census Bureau, pp. 1-13.

Collins, Patricia Hill. 2000. Black Feminist Thought: Knowledge, Consciousness, and the Politics of Empowerment. New York: Routledge. First published 1990

Daniel, G. Reginald, Laura Kina, Wei Ming Dariotis, and Camilla Fojas. 2014. Emerging paradigms in critical mixed race studies. Journal of Critical Mixed Race Studies 1: 1-65. [CrossRef]

Davenport, Lauren D. 2016. The role of gender, class, and religion in biracial Americans' racial labeling decisions. American Sociological Review 81: 57-84. [CrossRef]

Davis, Floyd James. 1991. Who Is Black? One Nation's Definition. State College, PA: Pennsylvania State University Press.

Deterding, Nicole M., and Mary C. Waters. 2018. Flexible coding of in-depth interviews: A twenty-first century approach. Sociological Methods \& Research 50: 1-32. [CrossRef]

Dixon, John A., Berenice Mahoney, and Roger Cocks. 2002. Accents of Guilt?: Effects of Regional Accent, Race, and Crime Type on Attributions of Guilt. Journal of Language and Social Psychology 21: 162-68. [CrossRef]

Echols, Leslie, and Sandra Graham. 2018. Meeting in the middle: The role of mutual biracial friends in cross-race friendships. Child Development 91: 401-16. [CrossRef] [PubMed]

Feliciano, Cynthia. 2016. Shades of Race: How Phenotype and Observer Characteristics Shape Racial Classification. American Behavioral Scientist 60: 390-419. [CrossRef] 
Fourcade, Marion, Etienne Ollion, and Yann Algan. 2015. The superiority of economists. Journal of Economic Perspectives 29: 89-114. [CrossRef]

Franco, Marisa G., and Stephen A. Franco. 2015. Impact of identity invalidation for black multiracial people: The importance of race of perpetrator. Journal of Black Psychology 42: 530-48. [CrossRef]

Freeman, Jonathan B., Kristin Pauker, and Diana T. Sanchez. 2016. A perceptual pathway to bias: Interracial exposure reduces abrupt shifts in real-time race perception that predict mixed-race bias. Psychological Science 27: 502-17. [CrossRef]

Gaither, Sarah E. 2018. The multiplicity of belonging: Pushing identity research beyond binary thinking. Self and Identity 17: 443-54. [CrossRef]

Gaither, Sarah E. 2019. Diversifying psychological science. Psychology Today. August 7. Available online: https:/ /www.psychologytoday. $\mathrm{com} / \mathrm{us} / \mathrm{blog} /$ different-identities-differentperspectives/201908/diversifying-psychological-science (accessed on 7 August 2019).

Gaither, Sarah E., Eva E. Chen, Kathleen H. Corriveau, Paul L. Harris, Nalini Ambady, and Samuel R. Sommers. 2014. Monoracial and biracial children: Effects of racial identity saliency on social learning and social preferences. Child Development 85: 2299-316. [CrossRef] [PubMed]

Gaither, Sarah E., Laura G. Babbitt, and Samuel R. Sommers. 2018. Resolving racial ambiguity in social interactions. Journal of Experimental Social Psychology 76: 259-69. [CrossRef]

Galinsky, Adam D., Erika V. Hall, and Amy J. C. Cuddy. 2013. Gendered races: Implications for interracial marriage, leadership selection, and athletic participation. Psychological Science 24: 498-506. [CrossRef] [PubMed]

Garay, Maria M., and Jessica D. Remedios. 2021. A review of White-centering practices in multiracial research in social psychology. Social and Personality Psychology Compass 15: e12642. [CrossRef]

Ghavami, Negin, and Letitia Anne Peplau. 2013. An intersectional analysis of gender and ethnic stereotypes: Testing three hypotheses. Psychology of Women Quarterly 37: 113-27. [CrossRef]

Hallinan, Maureen T., and Richard A. Williams. 1987. The stability of students' interracial friendships. American Sociological Review 52: 653-64. [CrossRef]

Harris, David R., and Jeremiah Joseph Sim. 2002. Who is multiracial? Assessing the complexity of lived race. American Sociological Review 67: 614-27. [CrossRef]

Herman, Melissa. 2004. Forced to choose: Some determinants of racial identification in multiracial adolescents. Child Development 75: 730-48. [CrossRef]

Hernández, Tanya Katerí. 2018. Multiracials and Civil Rights: Mixed-Race Stories of Discrimination. New York: New York University Press.

Hitlin, Steven, J. Scott Brown, and Glen H. Elder Jr. 2006. Racial self-categorization in adolescence: Multiracial development and social pathways. Child Development 77: 1298-308. [CrossRef]

Ho, Arnold K., Jim Sidanius, Daniel T. Levin, and Mahzarin R. Banaji. 2011. Evidence for hypodescent and racial hierarchy in the categorization and perception of biracial individuals. Journal of Personality and Social Psychology 100: 492-506. [CrossRef]

Ifekwunigwe, Jayne O. 1999. Scattered Belongings: Cultural Paradoxes of Race, Nation and Gender. London: Routledge.

Jacobs, Jerry A. 2013. In Defense of Disciplines: Interdisciplinarity and Specialization in the Research University. Chicago: University of Chicago Press.

Johnson, Kerri L., Jonathan B. Freeman, and Kristin Pauker. 2012. Race is gendered: How covarying phenotypes and stereotypes bias sex categorization. Journal of Personality and Social Psychology 102: 116-31. [CrossRef]

Joseph, Ralina L. 2013. Transcending Blackness: From the New Millennium Mulatta to the Exceptional Multiracial. Durham, NC: Duke University Press.

Joseph-Salisbury, Remi. 2018. Black Mixed-Race Men: Transatlanticity, Hybridity and 'Post-Racial' Resilience. Bingley: Emerald Group Publishing.

Khanna, Nikki. 2004. The Role of Reflected Appraisals in Racial Identity: The Case of Multiracial Asians. Social Psychology Quarterly 67: 115-31. [CrossRef]

Khanna, Nikki. 2010. 'If you're half Black, you're just Black': Reflected appraisals and the persistence of the one-drop rule. The Sociological Quarterly 51: 96-121. [CrossRef]

Khanna, Nikki. 2011. Biracial in America: Forming and Performing Racial Identity. Minneapolis, MN: Lexington Books.

Lee, Jennifer, and Frank D. Bean. 2004. America's changing color lines: Immigration, race/ethnicity, and multiracial identification. Annual Review of Sociology 30: 221-42. [CrossRef]

Lindsay, D. Stephen. 2015. Replication in psychological science. Psychological Science 26: 1827-32. [CrossRef]

Livingston, G. 2017. The Rise of Multiracial and Multiethnic Babies in the U.S. Pew Research Center. Available online: http://www. pewresearch.org/fact-tank/2017/06/06/the-rise-ofmultiracial-and-multiethnic-babies-in-the-u-s/ (accessed on 10 August 2021).

Long, Lisa, and Remi Joseph-Salisbury. 2019. Black mixed-race men's perceptions and experiences of the police. Ethnic and Racial Studies 42: 198-215. [CrossRef]

Lopez, Alejandra. 2003. Collecting and tabulating race/ethnicity data with diverse and mixed heritage populations: A case-study with US high school students. Ethnic \& Racial Studies 26: 931-61. [CrossRef]

MacLin, Otto H., and Roy S. Malpass. 2001. Racial Categorization of Faces: The Ambiguous Race Face Effect. Psychology, Public Policy, and Law 7: 98-118. [CrossRef]

Mallon, Ron. 2007. Human categories beyond non-essentialism. Journal of Political Philosophy 15: 146-68. [CrossRef] 
Menkin, Josephine A., Sha-Sha A. Guan, Daniel Araiza, Carmen E. Reyes, Laura Trejo, Sarah E. Choi, Phyllis Willis, John Kotick, Elizabeth Jimenez, Sina Ma, and et al. 2017. Racial/Ethnic Differences in Expectations Regarding Aging Among Older Adults. The Gerontologist 57: S138-S148. [CrossRef]

Mihoko Doyle, Jamie, and Grace Kao. 2007. Are racial identities of multiracials stable? Changing self-identification among single and multiple race individuals. Social Psychology Quarterly 70: 405-23. [CrossRef] [PubMed]

Morning, Ann. 2012. Multiraciality and Census Classification in Global Perspective. In International Perspectives on Racial and Ethnic Mixedness and Mixing. Edited by Edwards Rosalind, Suki Ali, Chamion Caballero and Miri Song. London and New York: Routledge, pp. 10-22.

Newman, Alyssa M. 2019. Desiring the standard light skin: Black multiracial boys, masculinity and exotification. Identities 26: 107-25. [CrossRef]

Nishina, Adrienne, and Melissa R. Witkow. 2020. Why developmental researchers should care about biracial, multiracial, and multiethnic youth. Child Development Perspectives 14: 21-27. [CrossRef]

Pauker, Kristin, Chanel Meyers, Diana T. Sanchez, Sarah E. Gaither, and Danielle M. Young. 2018. A review of multiracial malleability: Identity, categorization, and shifting racial attitudes. Social and Personality Psychology Compass 12: e12392. [CrossRef]

Pew Research Center. 2015. Multiracial in America: Proud, Diverse and Growing in Numbers. Washington, DC: Pew Research Center.

Pilgrim, Haley. 2021. "I wish I didn't look so White": Examining contested racial identities in second-generation Black-White Multiracials. Ethnic and Racial Studies 44: 2551-73. [CrossRef]

Pirtle, Whitney N. L. 2021. Racial States and Re-making Race: Exploring Coloured Racial Re- and De-formation in State Laws and Forms in Post-Apartheid South Africa. Sociology of Race and Ethnicity 7: 145-59. [CrossRef]

Plaut, Victoria C. 2010. Diversity science: Why and how difference makes a difference. Psychological Inquiry 21: 77-99. [CrossRef]

Poston, Walker Carlos. 1990. The biracial identity development model: A needed addition. Journal of Counseling E Development 69: 152-55. [CrossRef]

Rivas-Drake, Deborah, Eleanor K. Seaton, Carol Markstrom, Stephen Quintana, Moin Syed, Richard M. Lee, and Tiffany Yip. 2014. Ethnic and racial identity in adolescence: Implications for psychosocial, academic, and health outcomes. Child Development 85: 40-57. [CrossRef] [PubMed]

Roberts, Steven O., and Susan A. Gelman. 2017. Multiracial children's and adults' categorizations of multiracial individuals. Journal of Cognition and Development 18: 1-15. [CrossRef] [PubMed]

Roberts, Steven O., Carmelle Bareket-Shavit, Forrest A. Dollins, Peter D. Goldie, and Elizabeth Mortenson. 2020. Racial inequality in psychological research: Trends of the past and recommendations for the future. Perspectives on Psychological Science 15: 1295-309. [CrossRef] [PubMed]

Rockquemore, Kerry Ann. 1998. Between Black and White Exploring the "Biracial” experience. Race and Society 1: 197-212. [CrossRef]

Rockquemore, Kerry Ann. 2002. Negotiating the color line: The gendered process of racial identity construction among black/white biracial women. Gender \& Society 16: 485-503. [CrossRef]

Rockquemore, Kerry Ann, and David L. Brunsma. 2002. Socially embedded identities: Theories, typologies, and processes of racial identity among Black/White biracials. Sociological Quarterly 43: 335-56. [CrossRef]

Rockquemore, Kerry Ann, and David L. Brunsma. 2004. Negotiating racial identity: Biracial women and interactional validation. Women \& Therapy 27: 85-102. [CrossRef]

Rockquemore, Kerry A., and Tracey A. Laszloffy. 2005. Raising Biracial Children. Lanham: AltaMira Press.

Rockquemore, Kerry A., David L. Brunsma, and Daniel Delgado. 2009. Racing to theory or retheorizing race? Understanding the struggle to build a Multiracial identity theory. Journal of Social Issues 65: 13-34. [CrossRef]

Root, Maria P. 1998. Experiences and processes affecting racial identity development: Preliminary results from the Biracial sibling project. Cultural Diversity and Mental Health 4: 237-47. [CrossRef] [PubMed]

Roth, Wendy D., and Biorn Ivemark. 2018. Genetic options: The impact of genetic ancestry testing on consumers' racial and ethnic identities. American Journal of Sociology 124: 150-84. [CrossRef]

Sanchez, Diana T., Danielle M. Young, and Kristin Pauker. 2015. Exposure to racial ambiguity influences lay theories of race. Social Psychological and Personality Science 6: 382-90. [CrossRef]

Sanchez, Diana T., Sarah E. Gaither, Analia F. Albuja, and Zoey Eddy. 2020. How policies can address Multiracial stigma. Policy Insights from the Behavioral and Brain Sciences 7: 115-22. [CrossRef]

Saperstein, Aliya, and Andrew M. Penner. 2010. The race of a criminal record: How incarceration colors racial perceptions. Social Problems 57: 92-113. [CrossRef]

Shih, Margaret, and Dianat Sanchez. 2009. When race becomes even more complex: Toward understanding the landscape of multiracial identity and experiences. Journal of Social Issues 65: 1-11. [CrossRef]

Sims, Jennifer Patrice. 2016. Reevaluation of the influence of appearance and reflected appraisals for mixed-race identity: The role of consistent inconsistent racial perception. Sociology of Race and Ethnicity 2: 569-83. [CrossRef]

Sims, Jennifer Patrice. 2018. "As I've gotten older, I've kind of kept it real." Theorizing about mixed-race identity change over the life course. Paper presented at the Southern Sociological Society Conference, New Orleans, LA, USA, April 6.

Sims, Jennifer Patrice, and Remi Joseph-Salisbury. 2019. 'We were all just the Black kids:' Black mixed-race men and the importance of adolescent peer groups for identity development. Social Currents 6: 51-66. [CrossRef] 
Sims, Jennifer Patrice, and Chinelo L. Njaka. 2020. Mixed-Race in the US and UK: Comparing the Past, Present, and Future. Bingley: Emerald Publishing.

Sims, Jennifer Patrice, Whitney Laster Pirtle, and Iris Johnson-Arnold. 2020. Doing hair, doing race: The influence of hairstyle on racial perception across the US. Ethnic and Racial Studies 43: 2099-119. [CrossRef]

Song, Miri, and Peter Aspinall. 2012. Is racial mismatch a problem for young 'mixed race' people in Britain? The findings of qualitative research. Ethnicities 12: 730-53. [CrossRef]

Stockstill, Casey. 2018. Does asserting a non-Black identity elicit more positive evaluations? White observers' reactions to Black, Biracial, Multiracial, and White job applicants. Sociological Perspectives 61: 126-44. [CrossRef]

Straka, Brenda C., Sarah E. Gaither, Shawn K. Acheson, and Scott H. Swartzwelder. 2020. "Mixed" drinking motivations: A comparison of majority, multiracial, and minority college students. Social Psychological and Personality Science 11: 676-87. [CrossRef]

Tate, Shirley. 2005. Black Skins, Black Masks: Hybridity, Dialogism, Performativity. Aldershot: Ashgate Publishing.

Tate, Shirley. 2007. Black beauty: Shade, hair and anti-racist aesthetics. Ethnic and Racial Studies 30: 300-19. [CrossRef]

Thomas, Paul L. 2017. White men of academia have an "objectivity" problem. Huffington Post. June 7. Available online: https://www. huffpost.com/entry/more-on-white-men-of-academia-studentand-self-evaluation_b_593a8204e4b0b65670e56963 (accessed on 10 August 2021).

Thompson, Beverly. 2000. Fence sitters, switch hitters, and bi-bi-girls: An exploration of 'Hapa' and bisexual identities. Frontiers: A Journal of Women Studies 21: 171-80. [CrossRef]

Vankov, Ivan, Jeffrey Bowers, and Marcus R. Munafò. 2014. On the persistence of low power in psychological science. The Quarterly Journal of Experimental Psychology 67: 1037-40. [CrossRef]

Vasquez, Jessica M. 2010. Blurred borders for some but not 'others': Racialization, 'flexible ethnicity,' gender, and third-generation Mexican American identity. Sociological Perspectives 53: 45-71. [CrossRef]

Vazire, Simine. 2015. Editorial. Social Psychological \& Personality Science 7: 3-7. [CrossRef]

Waring, Chandra D. L., and Bandana Purkayastha. 2017. 'I'm a different kind of biracial': How Black/white biracial Americans with immigrant parents negotiate race. Social Identities 23: 614-30. [CrossRef]

Westerhof, Gerben J., Susan K. Whitbourne, and Gillian P. Freeman. 2012. The Aging Self in a Cultural Context: The Relation of Conceptions of Aging to Identity Processes and Self-Esteem in the United States and the Netherlands. The Journals of Gerontology 67: 52-60. [CrossRef] [PubMed]

Young, Danielle M., Diana T. Sanchez, Kristin Pauker, and Sarah E. Gaither. 2021. A meta-analytic review of hypodescent patterns in categorizing multiracial and racially ambiguous targets. Personality and Social Psychology Bulletin 47: 705-27. [CrossRef] [PubMed]

Zuberi, Tukufu, and Eduardo Bonilla-Silva, eds. 2008. White Logic, White Methods: Racism and Methodology. Lanham, MD: Rowman \& Littlefield Publishers. 